\title{
MUNICIPAL SOLID WASTE: REVERSE LOGISTICS PERFORMANCE DETERMINES OPPORTUNITY COST OF BULK TIPPING
}

\author{
Manfred Fehr ${ }^{1, *}$ and Humberto Ferreira Silva Minéu ${ }^{2}$ \\ ${ }^{1}$ Federal University - Geography, IG-UFU, Uberlândia, MG 38400 902, Brazil \\ ${ }^{2}$ Federal Institute of Education Science and Technology of Triângulo Mineiro, Ituiutaba, Minas Gerais, Brazil
}

Article Info: Received:

5 June 2020

Revised:

29 August 2020

Accepted:

11 September 2020

Available online:

28 December 2020

Keywords:

Dynamic opportunity cost

Landfill diversion

Municipal solid waste

Opportunity cost of landfill

Reverse logistics efficiency

\begin{abstract}
The opportunity cost concept refers to quantifying the opportunities lost upon choosing one investment option over a more economical alternative. The present study applies the concept to the process of choosing the best investment option for managing municipal solid waste. In a case study in Brazil, the options on the table are bulk collection and tipping versus reverse logistics with selective collection and sale of recovered components. The use of relative monetary values renders the results general and applicable in other scenarios. The bulk tipping option represents the reference cost of 100 . The research postulates a linear relation between the opportunity cost of bulk tipping (y) and the efficiency of reverse logistics operations ( $\mathrm{x}$ ). Zero efficiency means bulk collection and tipping of all waste. Full efficiency means capture of all recyclable items, which in the case study amount to $80 \%$ of waste. Various intermediate points confirm the relationship that takes the form $y=0.968 x$. The result shows that opportunity cost is dynamic in as much as changes of technologies and administrative procedures move it along that line. It also illustrates to municipal administrations the immediate economic effect of implementation and stepwise improvement of reverse logistics.
\end{abstract}

\section{INTRODUCTION}

Different countries apply different solutions to the municipal solid waste problem. Increasing urbanization has increased the competition for space in cities, and its value has risen to a point where landfills are no longer an obvious option for occupying that space. The more advanced options include mechanical-biological pretreatment, source separation, recycling and large-scale composting. The present research is concerned specifically with the situation prevailing in Brazil, where those options are not yet the rule. The administration of municipal waste is in the stage of transition from dumpsites to landfills, mandated by federal law (Brazil 2007, Brazil 2010). The law requires of municipal administrations that they create and implement local plans to eradicate dumpsites and provide collection service to all residences. The transition has progressed to $52 \%$, which means that $52 \%$ of the municipalities are already operating sanitary landfills. In this context, tipping all municipal waste at the landfills presently represents the solution to the waste problem. Diversion efforts are in their infancy. Of the $1.05 \mathrm{~kg}$ per person per day of waste collected, only 37 grams find their way into the reverse logistics chain (Brazil 2014). There is demand for research in order to move forward from this modest result. The present study uses the concept of opportunity cost accounting to identify economically viable alternatives to the landfill for the destination of municipal waste. The starting point is the expense reported for mixed collection and landfilling of municipal waste (Brazil 2014), whose average stands at BRL 109.96 per person per year. With the average national waste production of $1.05 \mathrm{~kg}$ per person per day, this translates into BRL 286.91 per tonne $(109.96 * 1000) /(1.05 * 365)$. The opportunity cost concept can point to other applications of this amount that are economically and environmentally more interesting.

The concept of opportunity cost originated in the School of Vienna in the early 20th century. It is defined as the value of a productive resource in economic theory (Pereira 1990, Wieser 1926). It is the study of scarcity with its resulting phenomena, like the need for choosing the best use of resources among various mutually exclusive options. It reflects the obligation of making choices (Santos 2000, Beuren 1993), and represents the value of a sacrificed alternate option of investment (New Oxford 2019). The value is time-dependent. If at the time the investment decision has to be made, only one destination of resources 
is known and considered urgent, there really is no choice and no sacrificed alternative. Consequently, there is no opportunity cost (Buchanan 2015). Even if at a later date, other opportunities appear for allocation of the same resources to the same end, the original decision may not be reversed, because it has been executed. As a result, opportunity cost is a dynamic and forward-looking concept. Buchanan (2015) also contents that any application of the opportunity cost concept to non-market settings requires analytical clarification in each particular case.

The present case study uses data from the municipality of Ituiutaba in central Brazil. Prior to 2005, the municipality operated a dumpsite. At the time, this was the only option available, and consequently had zero opportunity cost. With federal legislation asking for the elimination of dumpsites, those sites suddenly acquired opportunity costs as the viable and compulsory alternative of landfills arose. Consequently, the municipality constructed a landfill in 2005. Again, this was the only option on the horizon, and thus initially, had zero opportunity cost. The next viable alternative to appear in the municipality after the landfill was reverse logistics, which is the subject of the present study. Reverse logistics does not function instantaneously. It passes through sequential stages of success, during which the opportunity cost of the landfill increases until reaching a value that corresponds to the highest possible diversion rate. The opportunity cost of the reverse logistics procedure accompanies its stages of success. Every new stage burdens the previous one with an opportunity cost. The eventual future option will be "zero-waste", advocated by the Zero Waste International Alliance (ZWIA 2019), which is the logical endpoint of reverse logistics or its final stage of success. It has already been experimented with in small communities (Fehr 2012, Fehr 2014). That sequence of events illustrates the time dependence of opportunity costs, as mentioned earlier. The sequence may also be accelerated. Research is reported on that considers overriding certain steps, like progressing from dumpsites directly to reverse logistics and ignoring the landfill option (Veiga 2019). This would apply to municipalities who failed to advance during the time period when the landfill was the best viable alternative. The opportunity cost of dumpsites in the era of reverse logistics is enormous. It accumulated during the time of omission to construct the landfill. The opportunity cost of an investment option always reflects the time distance the decision maker remains behind the most modern technical and administrative options known and available.

The main objective of this communication is to provide a value for the opportunity cost of the bulk tipping option at a new landfill to be constructed in the municipality of Ituiutaba MG Brazil, with 103945 inhabitants (2014 census), considering reverse logistics as the best viable alternative at its various stages of success or efficiency. The originality resides in showing that the opportunity cost is dynamic, and is a function of reverse logistics efficiency.

The complementary objectives are as follows: Show the existence of hidden costs and lost opportunities inherent in the bulk tipping option. Provide an economic analysis to quantify the hidden costs. Quantify the benefits achievable with progressive reverse logistics. Challenge the paradigm of bulk tipping as solution to the waste problem. Illustrate the reasoning with a specific case and its specific data.

\section{METHODS}

The research needed to collect a great variety of information and data as basis for the calculation of opportunity costs. The qualitative part of this investigation consisted of establishing contacts within the community of stakeholders, through which it was then possible to arrive at the quantitative data on waste movement. The interaction was quite dynamic. As explained by Godoy (1995), qualitative research is not limited to asking questions and writing down the answers. The authors temporarily joined the teams of municipal administrators, real estate agents and operators of waste collection and tipping in order to create familiarity with the situation, gain insight and open up space for exchange of ideas. This type of procedure is in accordance with research schemes developed by Alencar and Gomes (1998) and by Foote and Whyte (1990). It also involved the participation of the authors in meetings and seminars. Eventually, it led to the identification of the correct persons for obtaining specific quantitative data on waste movement and costs. Through this interaction, the authors also gained access to specific documents within the municipal administration, like reports and budgets. Gil (2006) refers to this method as documental study.

The use of a case study was necessary in order to proceed to considerable depth in terms of a real-life situation that could use and expand existing theory, as mentioned by Yin (2001). In the case at hand, the sources of information were the various departments of the municipal administration, the autonomous municipal sanitation authority, the landfill operator and a cooperative of recyclers. The types of waste presently tipped at the landfill were identified as domestic waste, gardening discards, street cleaning output, sewage treatment sludge and institutional and commercial garbage. The time span of this research goes from 2007 to the publication of the first research report in 2016. Opportunity cost calculations involved the comparison between bulk collection and tipping as practiced now and a reverse logistics scheme as the most viable alternative. Various progressive stages of that scheme produced the corresponding opportunity costs of bulk tipping. A predictable outcome resulted, defined by a mathematical relationship between opportunity cost of bulk tipping and efficiency of reverse logistics. The following components entered the opportunity cost determination: landfill construction, equipment and its life span for the total tipping option, value of land occupied by the landfill and its vicinity, market values of residues tipped, costs of collection and landfill operation, costs of reverse logistics.

As for the calculation procedure, the authors followed the ideas of Buchanan (2015) and New Oxford (2019). As opportunity cost only exists at the moment of an investment decision, this study determined it to support the decision that will be on the table in 2020 when the present landfill in Ituiutaba reaches its capacity and has to be closed. Data collected for the last 10 years, both on collec- 
tion and landfill costs, and on the increasing reverse logistics operations, allowed for presenting and quantifying two options for the 2020 decision. Both options contain a landfill as inevitable component. Option 1 uses bulk collection and tipping of all trash. Option 2 invests in reverse logistics to divert part of the trash from the landfill and to tip only the rest. In order to render the results general and universal, the authors consider the bulk tipping cost as reference value, and determine all other costs and benefits relative to it.

\section{RESULTS}

\subsection{Present Situation in numbers}

The data collected on waste movement in Ituiutaba during the ten-year period from 2007 to 2016 show 218,725 tonnes collected and tipped. This means 60 tonnes per day. On an individual basis, it comes to $0.578 \mathrm{~kg}$ per person per day, which is well below the national average of $1.05 \mathrm{~kg}$ per person per day. The raw data obtained from the various sources consulted would only justify using three significant digits. In the following calculations, the authors retained as many digits as thought fit to allow the reader to accompany and verify the results, keeping in mind the three digit precision limit. Table 1 shows the composition of municipal waste. The first column represents "inert" components. The term "rejects" refers to mixed material that cannot be separated and allocated to inerts and biodegradables.

The composition report provides the recycling potential as $80.5 \%$ of waste. This value forms the natural final target for stepwise improvement of the reverse logistics operations over planned time intervals, and receives the designation of $100 \%$ reverse logistics efficiency in the subsequent calculations.

The expenditures for the ten-year period, obtained from the municipal budget and reduced to cost per year are detailed in the subsequent paragraphs.

\subsubsection{Tipping costs}

- Collection and tipping operations BRL 96.94/tonne.

- Landfill construction and maintenance operations BRL 59.45/tonne.

- Total BRL 156.39/tonne.

This value is below the national average estimated earlier. Expenditure with bulk collection and tipping in the ten-year period:

- BRL 156.39/tonne * 218,725 tonnes/10 years $=\mathrm{BRL}$ $3,420,640.28 /$ year.

TABLE 1: Composition of waste collected and tipped by weight.

\begin{tabular}{|c|c|c|c|c|}
\hline Paper, cardboard, tetrapak & $11.4 \%$ & & & \\
\hline Plastics & $16,4 \%$ & & & \\
\hline Glass & $2.1 \%$ & & & \\
\hline Metals & $1.8 \%$ & $31,7 \%$ & & \\
\hline Biodegradables & & $48,8 \%$ & $80,5 \%$ & \\
\hline Rejects & & & $19,5 \%$ & $100 \%$ \\
\hline
\end{tabular}

Source: Municipal Department of Urban Services

\subsubsection{Productivity of land occupied by landfill}

The average agricultural productivity of farmland around the city obtained from real estate agents and farmers is BRL 547.69 per hectare per year. The present landfill occupies 21.5 hectares (ha). The value sacrificed by occupying this area with the landfill amounts to $547.69 * 21.5=$ $11,775.34 \mathrm{BRL} /$ year.

The sum of the last two items BRL $3,420,640.28+$ $11,775.34=$ BRL 3,432,415.62/year forms the reference of 100 for opportunity cost calculations.

\subsubsection{Landfill diversion}

A functional reverse logistics scheme at its sequential stages of success or efficiency will divert increasing fractions of waste from the landfill and recycle them. The subsequent calculations relate the credit derived from those fractions to the reference value of 100 .

\subsubsection{Value of recycled material}

The average income for dry material from selective collection as reported by the recyclers' cooperative was BRL 434.07/tonne, considering the composition report of Table 1 and their operating expenses. This material represents $31.7 \%$ of the waste stream (Table 1 ) of $21,872.5$ tonnes/ year.

The average income for compost produced from biodegradable residue has been reported by Fehr (2016) as BRL $240.00 /$ tonne of residue. This material represents $48.8 \%$ of the waste stream (Table 1) of 21,872.5 tonnes/year.

\subsubsection{Expenditure with reverse logistics}

The municipal contribution to reverse logistics consists of providing selective collection infrastructure, and administrative and real estate support to a cooperative. The value obtained from the Municipal Department of Urban Services was BRL $254,024.88$ per year when $4 \%$ of waste were actually recycled. The subsequent calculations will adjust the value to different fractions of recycle.

\subsubsection{Taxes paid by the operators of reverse logistics}

The recyclers' cooperative with its present infrastructure and its present production rate pays taxes of BRL $58,321.52$ per year. In order to remain conservative, the calculations will not change this value for future situations.

\subsection{Opportunity cost}

Based on the data provided so far, Tables 2 to 7 detail the calculation of the opportunity cost of bulk tipping for various stages of reverse logistics efficiency.

Table 2 shows the division of waste between the landfill and recycling operations for various degrees of reverse logistics efficiency.

Table 3 defines the case of zero reverse logistics. The cost of the bulk tipping operation forms the reference value of 100 for opportunity cost calculations.

Table 4 illustrates the calculation procedure for arriving at a relative opportunity cost from a given value of reverse logistics efficiency. In this case, the reverse logistics 
TABLE 2: Material movement as function of reverse logistics efficiency for the waste composition of Table 1. Units: \% of waste.

\begin{tabular}{|c|c|c|c|c|c|}
\hline Reverse logistics efficiency & destination & inerts & biodegradables & rejects & total \\
\hline \multirow{2}{*}{$0 \%$} & recycled & 0 & 0 & 0 & 0 \\
\hline & tipped & 31.7 & 48.8 & 19.5 & 100 \\
\hline \multirow{2}{*}{$35 \%$} & recycled & 11.1 & 17.1 & 0 & 28.2 \\
\hline & tipped & 20.6 & 31.7 & 19.5 & 71.8 \\
\hline \multirow{2}{*}{$60 \%$} & recycled & 19.0 & 29.3 & 0 & 48.3 \\
\hline & tipped & 12.7 & 19.5 & 19.5 & 51.7 \\
\hline \multirow{2}{*}{$80 \%$} & recycled & 25.4 & 39.0 & 0 & 64.4 \\
\hline & tipped & 6.3 & 9.8 & 19.5 & 35.6 \\
\hline \multirow{2}{*}{$100 \%$} & recycled & 31.7 & 48.8 & 0 & 80.5 \\
\hline & tipped & 0 & 0 & 19.5 & 19.5 \\
\hline
\end{tabular}

Explanation of Table 2. Example 80\% reverse logistics efficiency. Inert material: Capture and recycle 80\% of 31.7 or 25.4. Tipping 31.7 - 25.4 = 6.3. Biodegradable material: Capture and recycle $80 \%$ of 48.8 or 39.0. Tipping $48.8-39.0=9.8$. Rejected material totally tipped 19.5 .

TABLE 3: Determination of the reference value for opportunity costs. Cost of waste handling with zero reverse logistics.

\begin{tabular}{|c|c|c|c|}
\hline \multirow[t]{4}{*}{ Expenses } & lost land productivity & $11,775.34 / 3,432,415.62=$ & 0.003431 \\
\hline & reverse logistics cost & 0 & 0 \\
\hline & tipping cost & $3,420,640.28 / 3,432,415.62=$ & 0.996569 \\
\hline & total expenses & & 1.000000 \\
\hline \multirow[t]{4}{*}{ Credits } & value of inert material & 0 & \\
\hline & value of compost & 0 & \\
\hline & taxes paid & 0 & \\
\hline & total credits & & 0 \\
\hline
\end{tabular}

Reference expenses are $1 * 100=100=3,432,415.62=$ actual expenses. Opportunity cost $=$ reference expenses - actual expenses $=1-1=0$

TABLE 4: Cost of waste handling for $35 \%$ reverse logistics efficiency relative to reference value (according to Table 2, reverse logistics captures $28.2 \%$ of waste).

\begin{tabular}{|c|c|c|c|}
\hline \multirow[t]{4}{*}{ Expenses } & lost land productivity & $11,775.34 * 0.718 / 3,432,415.62=$ & 0.002463 \\
\hline & reverse logistics cost & $254,024.88^{*}(0.282 / 0.04) / 3,432,415.62=$ & 0.521743 \\
\hline & tipping cost & $156.39 \star 21872.5 * 0.718 / 3,432,415.62=$ & 0.715537 \\
\hline & total expenses & & 1.239754 \\
\hline \multirow[t]{4}{*}{ Credits } & value of inert material & $21,872.5 * 0.111 * 434.07 / 3,432,415.62=$ & 0.307030 \\
\hline & value of compost & $21,872.5 * 0.171 * 240.00 / 3,432,415.62=$ & 0.261521 \\
\hline & taxes paid & $58,321.52 / 3,432,415.62=$ & 0.016991 \\
\hline & total credits & & 0.585542 \\
\hline
\end{tabular}

Net expenses $1.239754-0.585542=0.654212$

Opportunity cost $=$ reference expenses - actual expenses $=1-0.654212=0.345788$

Opportunity cost referred to $100=34.6$

Relation: opportunity cost / reverse logistics efficiency $=34.6 / 35=0.989$

Explanation of Table 4. Lost land productivity. Only $71.8 \%$ of waste is tipped. Reverse logistics cost adjusted from the experimental value for $4 \%$ recycle to $28.2 \%$ recycle. Tipping cost: $71.8 \%$ of 21872.5 tonnes of waste tipped at a cost of BRL 156.39 per tonne. Inert material: Recycle is $31.7 * 0.35=0.111$ of $21,872.5$ tonnes at BRL 434.07 per tonne. Value of compost: Recycle is $48.8 * 0.35=0.171$ of $21,872.5$ tonnes at BRL 240.00 per tonne.

efficiency of $35 \%$ leads to the relative opportunity cost of $34.6 \%$. The relationship is $34.6 / 35=0.989$.

Explanation of Table 4. Lost land productivity. Only $71.8 \%$ of waste is tipped. Reverse logistics cost adjusted from the experimental value for $4 \%$ recycle to $28.2 \%$ recycle. Tipping cost: $71.8 \%$ of 21872.5 tonnes of waste tipped at a cost of BRL 156.39 per tonne. Inert material: Recycle is $31.7 * 0.35=0.111$ of $21,872.5$ tonnes at BRL 434.07 per tonne. Value of compost: Recycle is $48.8 * 0.35=0.171$ of $21,872.5$ tonnes at BRL 240.00 per tonne.
Table 5 repeats the procedure for $60 \%$ reverse logistics efficiency leading to $58 \%$ relative opportunity cost. The relationship is $58.0 / 60=0.967$.

Table 6 repeats the procedure for $80 \%$ reverse logistics efficiency leading to $76.9 \%$ relative opportunity cost. The relationship is $76.9 / 80=0.961$.

Table 7 depicts the situation for $100 \%$ reverse logistics efficiency with the relative opportunity cost of $95.6 \%$. The relationship is $95.6 / 100=0.956$.

Admitting an error range of $2 \%$, the relation of opportu- 
TABLE 5: Cost of waste handling for $60 \%$ reverse logistics efficiency relative to reference value (according to Table 2, reverse logistics captures $48.3 \%$ of waste).

\begin{tabular}{|c|c|c|c|}
\hline \multirow[t]{4}{*}{ Expenses } & lost land productivity & $11,775.34 * 0.517 / 3,432,415.62=$ & 0.001774 \\
\hline & reverse logistics cost & $254,024.88 *(0.483 / 0.04) / 3,432,415.62=$ & 0.893642 \\
\hline & tipping cost & $156.39 \star 21872.5 \star 0.517 / 3,432,415.62=$ & 0.515226 \\
\hline & total expenses & & 1.410642 \\
\hline \multirow[t]{4}{*}{ Credits } & value of inert material & $21,872.5 * 0.190 * 434.07 / 3,432,415.62=$ & 0.525548 \\
\hline & value of compost & $21,872.5 * 0.293 * 240.00 / 3,432,415.62=$ & 0.448103 \\
\hline & taxes paid & $58,321.52 / 3,432,415.62=$ & 0.016991 \\
\hline & total credits & & 0.990642 \\
\hline \multicolumn{4}{|c|}{$\begin{array}{l}\text { Net expenses } 1.410642-0.990642=0.420000 \\
\text { Opportunity cost }=\text { reference expenses }- \text { actual expenses }=1-0.420000=0.580000 \\
\text { Opportunity cost referred to } 100=58.0 \\
\text { Relation: opportunity cost / reverse logistics efficiency }=58.0 / 60=0.967\end{array}$} \\
\hline \multicolumn{4}{|c|}{ Explanation of Table 5. Same procedure as Table 4.} \\
\hline
\end{tabular}

TABLE 6: Cost of waste handling for $80 \%$ reverse logistics efficiency relative to reference value (according to Table 2, reverse logistics captures $64.4 \%$ of waste).

\begin{tabular}{|c|c|c|c|}
\hline \multirow[t]{4}{*}{ Expenses } & lost land productivity & $11,775.34 * 0.356 / 3,432,415.62=$ & 0.001221 \\
\hline & reverse logistics cost & $254,024.88 *(0.644 / 0.04) / 3,432,415.62=$ & 1.191523 \\
\hline & tipping cost & $156.39 * 21,872.5 * 0.356 / 3,432,415.62=$ & 0.354779 \\
\hline & total expenses & & 1.547523 \\
\hline \multirow[t]{4}{*}{ Credits } & value of inert material & $21,872.5 * 0.254 * 434.07 / 3,432,415.62=$ & 0.702575 \\
\hline & value of compost & $21,872.5 * 0.390 * 240.00 / 3,432,415.62=$ & 0.596451 \\
\hline & taxes paid & $58,321.52 / 3,432,415.62=$ & 0.016991 \\
\hline & total credits & & 1.316017 \\
\hline
\end{tabular}

Net expenses $1.547523-1.316017=0.231506$

Opportunity cost $=$ reference expenses - actual expenses $=1-0.231506=0.768494$

Opportunity cost referred to $100=76.9$

Relation: opportunity cost / reverse logistics efficiency $=76.9 / 80=0.961$

Explanation of Table 6. Same procedure as Table 4.

TABLE 7: Cost of waste handling for $100 \%$ reverse logistics efficiency relative to reference value (according to Table 2, reverse logistics captures $80.5 \%$ of waste).

\begin{tabular}{|c|c|c|c|}
\hline \multirow[t]{4}{*}{ Expenses } & lost land productivity & $11,775.34 * 0.195 / 3,432,415.62=$ & 0.000669 \\
\hline & reverse logistics cost & $254,024.88 *(0.805 / 0.04) / 3,432,415.62=$ & 1.489403 \\
\hline & tipping cost & $156.39 * 21872.5 \star 0.195 / 3,432,415.62=$ & 0.194331 \\
\hline & total expenses & & 1.684403 \\
\hline \multirow[t]{4}{*}{ Credits } & value of inert material & $21,872.5 * 0.317 * 434.07 / 3,432,415.62=$ & 0.876834 \\
\hline & value of compost & $21,872.5^{\star} 0.488 \star 240.00 / 3,432,415.62=$ & 0.746328 \\
\hline & taxes paid & $58,321.52 / 3,432,415.62=$ & 0.016991 \\
\hline & total credits & & 1.640153 \\
\hline
\end{tabular}

Net expenses $1.684403-1.640153=0.044250$

Opportunity cost $=$ reference expenses - actual expenses $=1-0.044250=0.955750$

Opportunity cost referred to $100=95.6$

Relation: opportunity cost / reverse logistics efficiency $=95.6 / 100=0.956$

Explanation of Table 7. Same procedure as Table 4.

nity cost $(y)$ to reverse logistics efficiency $(x)$ is constant at 0.968 . This leads to the equation of a straight line: $y=0.968 x$ from which to predict the opportunity cost.

The total economic cost of choosing bulk tipping is the sum of the expense actually occurred and the savings sacrificed for each stage of reverse logistics efficiency. For example, in the case of $80 \%$ reverse logistics efficiency, the economic cost is $100+76.9$ or $176.9 \%$ of the investment actually made. Here lies the power of the opportunity cost concept. It shows hidden items that are not visible in the municipal budget. In fact, the budget only reports an expense of 100 for bulk tipping, whereas the real cost of this option is 176.9 because it sacrifices savings of 76.9 by not choosing the alternate option available. This is the 
message to the municipal administration for the decision process on schedule for 2020 .

\section{DISCUSSION}

The present landfill in the city under study has been in operation since 2005 and will reach its projected capacity in 2020. At that time, it will have to be closed, and a new decision on the continuity of municipal solid waste management will have to be made. In 2005 , bulk collection and tipping was the only option on the table in the city. The reason: Federal law at the time asked for moving from dumpsites to landfills, and there was no experience with reverse logistics.

In the last ten years, however, reverse logistics operations with selective collection appeared on the scene and produced numbers on recycling, which were missing heretofore. Consequently, in 2020, there will be at least two options of investment. The first option is to construct a new landfill and continue with the bulk collection and tipping scheme. The second option is to invest in reverse logistics and target the ideal recycling rate of $80.5 \%$ of all waste, or else target intermediate recycling rates at the choice of the administration for planned time intervals. The present research collected data on both options during the last ten years, and compared the two investment choices. As an original contribution to the decision process, it developed an equation relating the efficiency of reverse logistics to opportunity cost. The municipal administration can now use the results for making the decision in 2020. In relative yearly terms, the first option requires and investment of 100 monetary units per year. The ideal second option solves the same problem with an investment of 4.4 (100 - 95.6) monetary units per year. It consists of organizing reverse logistics in order to recycle $80.5 \%$ of all waste, i.e. sell the selected inert components and sell compost produced from the biodegradable components. The difference of 95.6 monetary units becomes available for other uses in the municipal budget and thus represents the opportunity cost of choosing the first option. In economic terms, the real cost of choosing the first option is a surprising 195.6 monetary units, which consist of the investment proper of 100 and the credits of 95.6 sacrificed by ruling out the second option. The merit of this research resides in providing data for the imminent decision on the continuity of waste management in the city, on the table for 2020 when the present landfill will be closed, and in quantifying the opportunity cost of the landfill at a time when administrative and technical means are available to operate a reverse logistics scheme.

The data and calculations specifically refer to the case study, but the method is general. The most impressive contribution of opportunity cost accounting to investment decisions concerning municipal waste management resides in the fact that it identifies credits possible with alternate procedures, which are not visible in the budget. In the case at hand, the budget shows the investment of 100 for the new landfill, but does not show the savings of 95.6 obtainable with the alternate procedure. The study confirmed the dynamic nature of opportunity costs. Within the ten-year period considered, the cost of building and operating the landfill stayed constant at 100 , but its opportunity cost rose from zero to a maximum of 95.6 as a consequence of the appearance of a viable alternative with a price tag of only 4.4 units.

As a case study, this research provided specific data on the situation in the municipality of Ituiutaba in 2016. The data are specific, but the procedure can possibly be extrapolated and thus be useful in other municipal contexts. The idea of an equation relating opportunity cost to reverse logistics efficiency is both original and generally applicable, although its precise form may vary from locality to locality. The equation represents a very visible guide for starting and expanding reverse logistic programs that move any municipality beyond strict legal requirements to eliminate the dumpsites.

\section{CONCLUSIONS}

The study attained its main objective, which was to provide a value for the opportunity cost of tipping all waste at a landfill in the municipality of Ituiutaba MG Brazil, with 103945 inhabitants (2014 census), in view of an investment decision to be reached in 2020 when reverse logistics will be available as the best viable alternative. The study also attended to complementary objectives. It identified the hidden costs of a landfill that do not appear in the municipal budget and refer to benefits derived from recycling part of the waste and to liberating part of the land occupied by the landfill.

The investment figures for the various items of the available options were translated into relative monetary units in order to make the results more comprehensible to an international audience.

The investment required in the landfill as the only destination was considered the reference of 100 in the context of working with relative monetary units.

The alternative of reverse logistics at different stages of efficiency required investments in the range of $100(0 \%$ reverse logistics) to 4.4 (100\% reverse logistics) to solve the same problem, namely manage municipal waste. Consequently, the opportunity cost of the landfill is dynamic and increases with improving reverse logistics. The research produced the equation $y=0.968 \times$ to predict the opportunity cost y resulting from any reverse logistics efficiency $x$.

The economic value of the investment in the landfill for $100 \%$ reverse logistics efficiency was 195.6 comprising the sunk money invested and the opportunities lost by excluding the better alternative.

The study illustrated the dynamic nature of opportunity costs by showing their time dependence. An opportunity cost of an investment decision only exists if at the time of the decision a better alternative for applying the resources is known, available and technically mature for implementation.

In the context of the case study, the landfill constructed in 2005 had no opportunity cost because no better alternative for managing municipal waste was obvious in the city. During the following ten years, reverse logistics operators 
gained experience and produced numerical information. Consequently, at the time of the next investment decision, due in 2020, the opportunity cost of a landfill in the city will be in the range of zero to 95.6 compared to its budget cost of 100 , depending on the target chosen for reverse logistics efficiency. In essence, the research challenged the landfill as destination of municipal waste by showing the viability of a cheaper alternative.

\section{REFERENCES}

Allenare, E; Gomes, M. A. 1998, Metodologia de pesquisa social e diagnóstico participativo (Social research methodology and participative diagnosis), UFLA/FAEPE, Lavras, Brazil

Beuren, I. M. 1993, Conceituação e contabilização do custo de oportunidade (Conceptualization and use in accounting of the opportunity cost), FIPECAFI - Caderno de Estudos, $n^{\circ} 08$, São Paulo, Brazil

Brazil 2007. Law $n^{\circ} 11.445$ on basic sanitation, http://www.planalto. gov.br/ccivil_03/_ato2007-2010/2007/lei/l11445.html, Access 20160415

Brazil 2010. Law $n^{\circ} 12.305$ on the national policy for solid waste. http://www.planalto.gov.br/ccivil_03/_ato2007-2010/2010/lei/ 112305.htm Access 20111013

Brazil 2014. Ministry of Cities. National Information System on Sanitation. Diagnosis of urban waste management. http://www.snis.gov. br/diagnostico-residuos-solidos Access 20160319

Buchanan, J.M. 2015, Opportunity Cost, The New Palgrave Dictionary of Economics, http://www.link.springer.com/referenceworkentry/ 10.1057\%2F978-1-349-95121-5_1433-2 (access 201908 20)

Fehr, M. 2012, Zero waste in the apartment: we made it (invited forum paper), International Journal of Environment and Waste Management, Inderscience International, ISSN 14789876 (print) and 1478 9868 (electronic) , vol. 10 no. 1 paper 9 pp. 112-113, http://dx.doi. org/10.1504/IJEWM.2012.048159, (access 201908 15)
Fehr, M. 2014, Register now for the residue world cup (guest editorial) Waste Management \& Research, The official journal of ISWA SAGE Publications International ISSN 0734 242X eISSN 10963669 vol. 32 no. 9 supplement pp. 1-2, http://dx.doi. org/10.1177/0734242X14537869 (access 201908 15)

Fehr, M. 2016A reciclagem de resíduos biodegradáveis municipais é viável (artigo convidado), (Recycling of biodegradable municipal residue is viable (invited paper), Ciência \& Cultura, ISSN 2317 6660 , SBPC Sociedade Brasileira para o Progresso da Ciência BR, Vol. 68 no. 4 pp. 44-45 outubro - dezembro 2016, http://dx.doi. org/10.21800/2317-66602016000400014

Foote-Whyte, W. 1990, Treinando a observação participante (Training participative observation), In: GUIMARÃES, Alba Zaluar. Desvendando máscaras sociais, Third edition, Francisco Alves, Rio de Janeiro, Brazil, pp. 77-86.

Gil, A. C. 2006, Métodos e técnicas de pesquisa social (Methods and techniques of social research), Fifth edition, Atlas, São Paulo, Brazil

Godoy, A. S. 1995, Introdução à pesquisa qualitativa e suas possibilidades (Introduction to qualitative research and its possibilities) RAE, São Paulo, Brazil, v. 35, n. 2, p. 57-63, March/April.

New Oxford American Dictionary 2019, http://www.oxfordreference. com (access 201908 20)

Pereira, A. C. et. al. 1990, Custo de Oportunidade: Conceitos e Contabilização (Opportunity cost: concept and accounting), FIPECAFI Caderno de Estudos n 02, São Paulo, Brazil

Santos, R. V. 2000, Aplicação do custo de oportunidade às decisões de preço de renda sob o enfoque do custeio direto (Application of opportunity cost to determining rental prices), lob Informações Objetivas Temática Contábil e Balanços

Veiga, R.M. 2019, From dumpsites to the circular economy, Ph.D. thesis, Federal University at Uberlândia MG Brazil

Wieser, F. von, 1851-1926, School of Vienna, mentioned in Pereira 1990

Yin, R. K. 2001, Estudo de caso: planejamento e métodos (Case study: planning and methods), Second edition, Bookman, Porto Alegre, Brazil

Zero Waste International Alliance 2019, http://www.zwia.org (access 201908 15) 